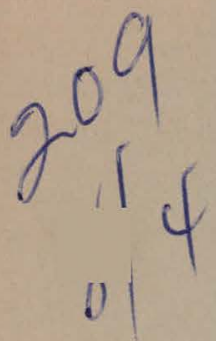

June 25, 1969

RFP-1151

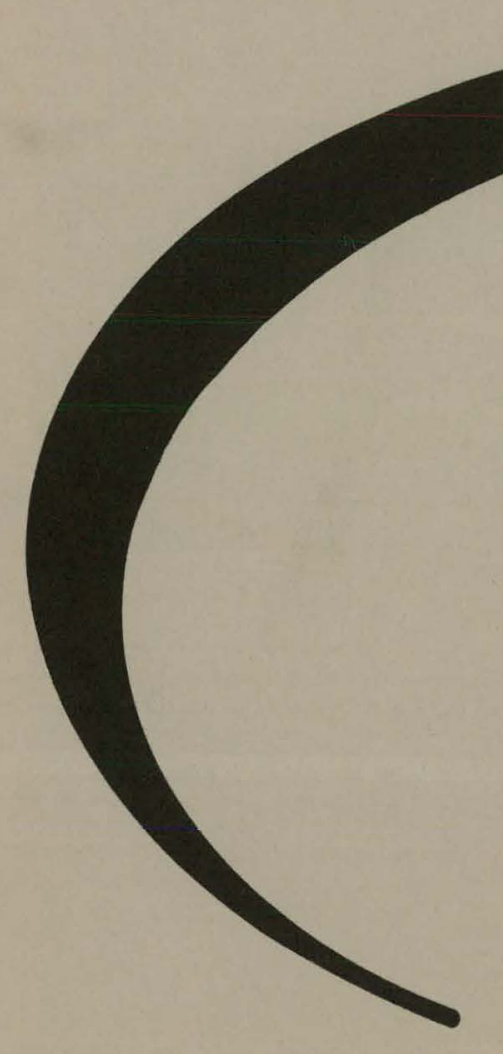

DISSOLUTION OF PLUTONIUM

TETRAFLUORIDE IN NITRIC ACID

James D. Navratil

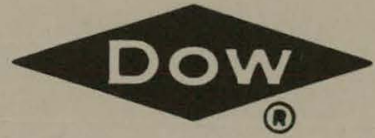

THE DOW CHEMICAL COMPANY ROCKY FLATS DIVISION

P. O. BOX 888

GOLDEN, COLORADO 80401

U.S. ATOMIC ENERGY COMMISSION

CONTRACT AT(29-1)-1106 


\section{DISCLAIMER}

This report was prepared as an account of work sponsored by an agency of the United States Government. Neither the United States Government nor any agency Thereof, nor any of their employees, makes any warranty, express or implied, or assumes any legal liability or responsibility for the accuracy, completeness, or usefulness of any information, apparatus, product, or process disclosed, or represents that its use would not infringe privately owned rights. Reference herein to any specific commercial product, process, or service by trade name, trademark, manufacturer, or otherwise does not necessarily constitute or imply its endorsement, recommendation, or favoring by the United States Government or any agency thereof. The views and opinions of authors expressed herein do not necessarily state or reflect those of the United States Government or any agency thereof. 


\section{DISCLAIMER}

Portions of this document may be illegible in electronic image products. Images are produced from the best available original document. 


\section{LEG A L NOTICE}

This report was prepared as an account of Government sponsored work. Neither the United States, nor the Atomic Energy Commission, nor any person acting on behalf of the Commission:

A. Makes any warranty or representation, expressed or implied, with respect to the accuracy, completeness, or usefulness of the information contained in this report, or that the use of any information, apparatus, method, or process disclosed in this report may not infringe privately owned rights; or

B. Assumes any liabilities with respect to the use of, or for damages resulting from the use of any information, apparatus, method, or process disclosed in this report.

As used in the above, "person acting on behalf of the Commission" includes any employee or contractor of the Commission, or employee of such contractor, to the extent that such employee or contractor of the Commission, or employee of such contractor prepares, disseminates, or provides access to, any information pursuant to his employment or contract with the Commission, or his employment with such contractor.

\section{Printed in the United States of America}

Available from

Clearinghouse for Federal Scientific and Technical Information

National Bureau of Standards, U. S. Department of Commerce

Springfield, Virginia 22151

Price: Printed Copy $\$ 3.00$; Microfiche $\$ 0.65$ 


\section{DISCLAIMER}

The enclosed document has not received any secondary reviews by the U.S. Department of Energy's Office of Scientific and Technical Information (OSTI) for public releasability. It is being made available with the understanding that any additional distribution is the responsibility of the receiving organization/individual. Any distribution outside the DOE community may require additional reviews in compliance with Secretary Abraham's May 30, 2002, memorandum titled "Safeguarding Information Pertaining to Weapons of Mass Destruction and Other Sensitive Information." 


\section{DISSOLUTION OF PLUTONIUM \\ TETRAFLUORIDE IN NITRIC ACID \\ James D. Navrat/l}

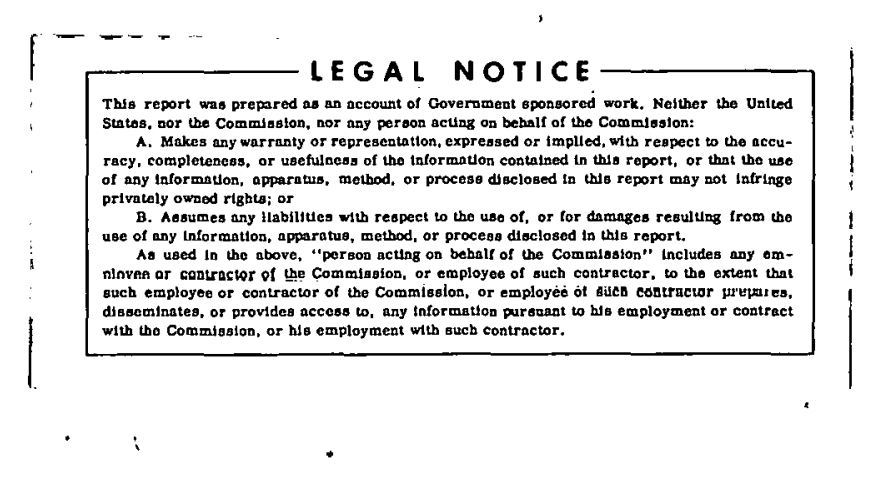

THE - DOW CHEMICAL COMPANY

ROCKY FLATS DIVISION

P. O. BOX 888

GOLDEN, COLORADO 80401

Prepared under Contract AT(29.1)-1106

for the

Albuquerque Operations Office

U. S. Atomic Energy Commission 
RFP-1151 


\section{CONTENT}

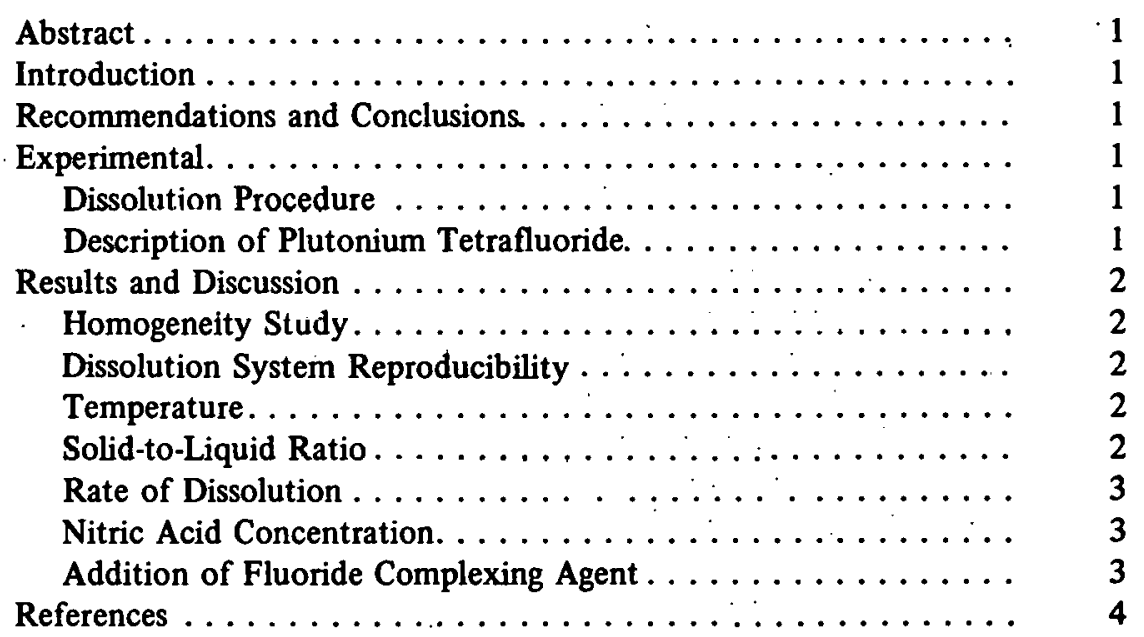




\section{ACKNOWLEDGMENT}

The author thanks Gary F. Molen for his initiative and help during this investigation and Yvonne M. Ferris for performing the statistical analyses. I wish also to thank the Radioassay Laboratory Group, which is under the direction of N. E. Moody, for their cooperation in performing the plutonnium analyses. 


\title{
DISSOLUTION OF PLUTONIUM TETRAFLUORIDE IN NITRIC ACID
}

\author{
James D. Navratil
}

\begin{abstract}
The optimum conditions for plutonium tetrafluoride dissolution in nitric acid were investigated and found to be solid-to-liquid ratio of 100 to $150 \mathrm{~g} / \mathrm{l}$, reflux and stirring for up to 2 hours, nitric acid concentration of 12.14 molar, and addition of boric acid or aluminum nitrate as a fluoride ion complexing agent.
\end{abstract}

\section{INTRODUCTION}

Aqueous processing of plutonium tetrafluoride in nitric acid requires rapid dissolution for minimum exposure of the operator to neutron radiation. Optimum dissolution conditions for plutonium tetrafluoride have not been reported except for a study concerning the dissolution of impure plutonium tetrafluoride. ${ }^{1}$ The solubility of plutonium tetrafluoride in nitric acid and nitric-hydrofluoric acid systems have been reported. ${ }^{2-5}$

Due to the lack of dissolution information, a study was initiated to determine the optimum conditions for plutonium tetrafluoride dissolution. The following factors were investigated at room temperatures $\left(25^{\circ}-30^{\circ} \mathrm{C}\right)$ and reflux $*\left(95^{\circ}-115^{\circ} \mathrm{C}\right)$ temperatures:

1. Optimum solid-to-liquid ratio.

2. The rate of dissolution.

3. The optimum nitric acid concentration.

4. The effect of fluoride ion complexing agents.

This report summarizes the results of this study.

\section{RECOMMENDATIONS AND CONCLUSIONS}

The optimum conditions determined for plutonium tetrafluoride dissolution in nitric acid are as follows:

1. Solid-to-liquid ratio of 100 to $150 \mathrm{~g} / \mathrm{l}$.

2. Reflux and stirring for up to 2 hours.

3. Nitric acid concentration of 12-14 molar.

\footnotetext{
"The reflex temperature varied with acid concentration. For example, at this laboratory (elevation 6000 feet) $1 \mathrm{M} \mathrm{HNO}$ refluxes at $95^{\circ} \mathrm{C}$ and $15.7 \mathrm{M} \mathrm{HNO}$ refluxes at $115^{\circ} \mathrm{C}$.
}

4. Addition of boric acid or aluminum nitrate as a fluoride ion complexing agent.

These optimum conditions were investigated on a laboratory scale, but they should also be evaluated on a production scale.

If the resulting plutonium nitrate solution is to be treated with hydrogen peroxide or calcium oxalate to precipitate and subsequently recover the plutonium, the amount of carry over of the fluoride complexing agent into the peroxide should be investigated.

\section{EXPERIMENTAL}

Dissolution Procedure: The dissolution of plutonium tetrafluoride was generally performed in a 125 - $\mathrm{ml}$ Florence flask containing 12.5 grams of solid and 50.0 milliliters of the desired solvent. After the contents of the flask had reached the desired temperature, it was stirred for 1.0 hour on a Thermolyne Stir Plate. The flask was fitted with a 12-inch-long water cooled condenser to maintain solution volume.

After the stirring was terminated, the condenser was rinsed with $0.5 \mathrm{M} \mathrm{HNO}_{3}$ and the solution brought to room temperature. Next, the solution was filtered through Whatman No. 42 filter paper into a $250-\mathrm{ml}$ volumetric flask. The residue was washed with $0.5 \underline{\mathrm{M}}$ nitric acid until the $250-\mathrm{ml}$ mark was reached. Finally the solution was mixed, sampled in duplicate, and each sample was analyzed twice for plutonium by radiometric techniques.

Description of Plutonium Tetrafluoride: The batch of plutonium tetrafluoride used for this study was obtained from the production hydrofluorinator at Rocky Flats. This material is typical of the plutonium tetrafluoride which is reduced to the metal. It contained approximately $6 \% \mathrm{PuO}_{2}$ as the major impurity, approximately $500 \mathrm{ppm}$ of $\mathrm{Ca}$ as the minor impurity, and was $76.6 \%$ Pu.

To determine the homogeneity of the material, six samples were analyzed twice for $\mathrm{g} / \mathrm{g}$ Pu by a fusion-redox titration method, percent $F$ by neutron counting, percent $\mathrm{PuO}_{2}$ and crystallite size by $\mathrm{x}$-ray diffraction, and surface area using the Brunauer, Emmett, and Teller (BET) adsorption technique. 
RFP-1151

\section{RESULTS AND DISCUSSION}

Homogeneity Study: The results of the homogeneity study are presented in Table I. The standard deviation between the samples is less than the standard deviation within the samples. On this basis the material can be considered statistically homogeneous.

Table I. Homogeneity of plutonium tetrafluoride (six samples analyzed in duplicate).

\begin{tabular}{|c|c|c|c|c|c|}
\hline $\begin{array}{l}\text { Sample } \\
\text { Number }\end{array}$ & $\begin{array}{c}\mathrm{Pu} \\
(\mathrm{g} / \mathrm{g})\end{array}$ & $\begin{array}{c}\text { Surface } \\
\text { Area }\left(\mathrm{m}^{2} / \mathrm{g}\right)\end{array}$ & $\begin{array}{l}\text { Crystallite Size } \\
\text { of the } \mathrm{PuO}_{2}(\AA)\end{array}$ & $\begin{array}{c}\text { Fluoride } \\
(\%)\end{array}$ & $\begin{array}{c}\mathrm{PuO}_{2} \\
(\%)\end{array}$ \\
\hline \multirow[t]{2}{*}{1} & 0.7671 & 0.20 & 4000 & 18.5 & 6.3 \\
\hline & 0.7633 & 0.54 & 5000 & 18.6 & 6.7 \\
\hline \multirow[t]{2}{*}{2} & 0.7653 & 0.31 & 3300 & 18.5 & 7.0 \\
\hline & 0.7657 & 0.44 & 5000 & 18.7 & 6.3 \\
\hline \multirow[t]{2}{*}{3} & 0.7675 & 0.23 & 5000 & 18.6 & 6.5 \\
\hline & 0.7672 & 0.53 & 3300 & 18.6 & 6.5 \\
\hline \multirow[t]{2}{*}{4} & 0.7678 & 0.26 & 4000 & 18.6 & 6.4 \\
\hline & 0.7674 & 0.23 & 5000 & 18.6 & $6: 3$ \\
\hline \multirow[t]{2}{*}{5} & 0.7669 & 0.30 & 3300 & 18.5 & 6.1 \\
\hline & 0.7678 & 0.22 & 3300 & 18.6 & 5.8 \\
\hline \multirow[t]{2}{*}{6} & 0.7666 & 0.23 & 6500 & 18.7 & 5.7 \\
\hline & 0.7678 & 0.36 & 4000 & 18.7 & 6.5 \\
\hline \multicolumn{6}{|c|}{ Standard } \\
\hline \multirow{2}{*}{\multicolumn{6}{|c|}{ Within }} \\
\hline & & & & & \\
\hline \multicolumn{6}{|l|}{ Standard } \\
\hline Deviation & 0.00064 & $\langle 0.143$ & $\langle 1081.3$ & 0.02 & 0.12 \\
\hline \multicolumn{6}{|l|}{ Between } \\
\hline Samples & & & & & \\
\hline
\end{tabular}

Dissolution System Reproducibility: The reproducibility of the dissolution system at room temperature $\left(25^{\circ}-30^{\circ} \mathrm{C}\right)$ and reflux temperatures $\left(95^{\circ}-115^{\circ} \mathrm{C}\right)$ was evaluated under similar conditions. The conditions and results are presented in Table II. The relative standard deviation of the percent plutonium dissolved at room temperature was $12.2 \%$. The relative standard deviation at reflux conditions was $6.2 \%$. Forty-five percent more plutonium dissolved under refluxing than at room temperature.

Temperature: Plutonium tetrafluoride samples (12.5 grams) and $50 \mathrm{ml}$ of $3 \underline{\mathrm{M}} \mathrm{HNO}_{3}+0.05 \underline{\mathrm{M} \mathrm{Al}}\left(\mathrm{NO}_{3}\right)_{3} \cdot 9 \mathrm{H}_{2} \mathrm{O}$ were stirred for one hour at $28^{\circ}, 46^{\circ}, 61^{\circ}, 75^{\circ}, 80^{\circ}$, and $96^{\circ} \mathrm{C}$. The percent plutonium dissolved in one hour increases with increasing temperature as shown in Figure 1.

Solid-to-Liquid Ratio: Plutonium tetrafluoride samples $(5,7.5,10,12.5$, and 15 grams) were contacted with 50 $\mathrm{ml}$ of solvent at room and reflux temperatures as described in the experimental procedure. The effect of these various solid-to-liquid ratios on the dissolution of plutonium tetrafluoride is presented in Table III. Note that the maximum

Table Il. Reproducibility of the dissolution system. Solvent: $3 \mathrm{M} \mathrm{HNO}_{3}+0.05 \underline{\mathrm{M}} \mathrm{Al}\left(\mathrm{NO}_{3}\right)_{3} \cdot\left(\mathrm{H}_{2} \mathrm{O}\right.$. Solid-to-liquid ratio $250 \mathrm{~g} / \mathrm{l}$. Stir time: 1 hour.

Experiment Number

Plutonium Dissolved (\%)

Room Temp. Reflux Temp.

1
2
3
4
5

Room Temp. Reflux Temp.

$\begin{array}{lcc} & 8.2 & 14.9 \\ & 7.7 & 14.8 \\ & 9.5 & 16.5 \\ & 1.2 & - \\ & 9.4 & - \\ & & \\ \text { Mean } & 8.4 & 15.4 \\ \text { S.D. } & 1.02 & 0.95 \\ \text { R.S.D. } \quad 12.2 \% & 6.2 \%\end{array}$

Figure 1. The effect of temperature on the dissolution of plutonium tetrafluoride. Solvent: $3 \underline{\mathrm{M}} \mathrm{HNO}_{3}+0.05 \underline{M}$ $\mathrm{Al}\left(\mathrm{NO}_{3}\right)_{3} \cdot 9 \mathrm{H}_{2} \mathrm{O}$. (Solid-to-liquid ratio $250 \mathrm{~g} / \mathrm{l}$. Stir time: 1 hour).

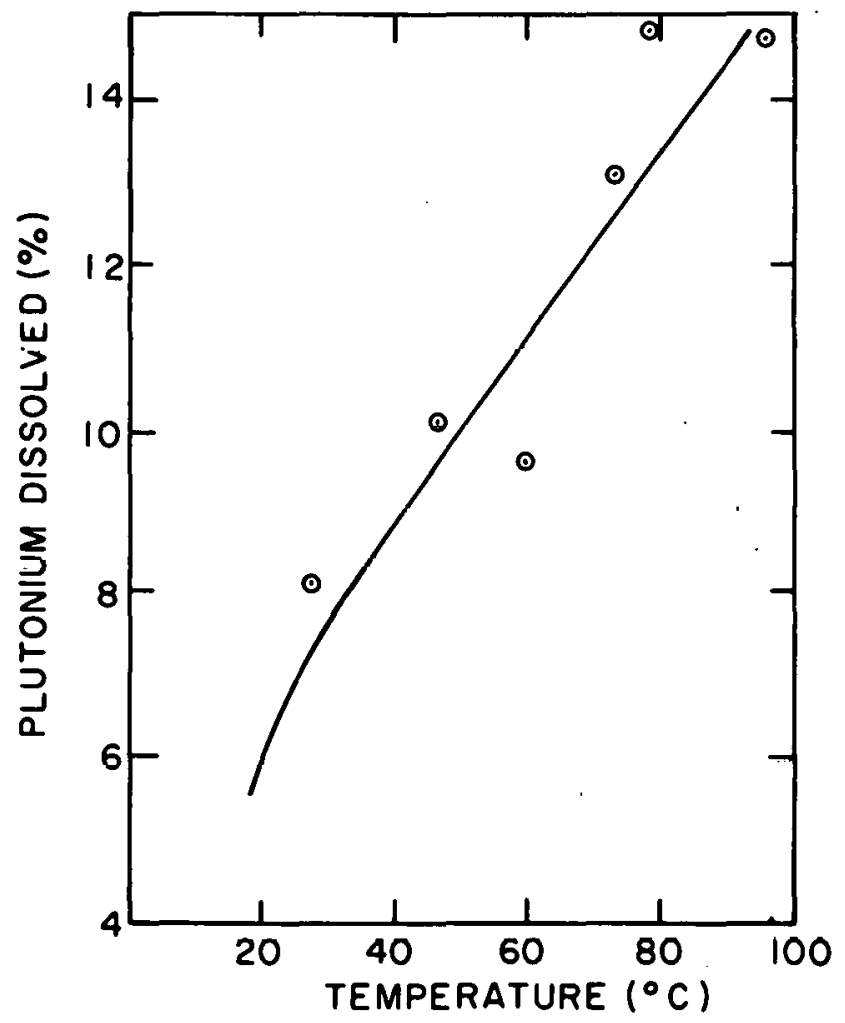


Table III. The effect of various solid-to-liquid ratios on the dissolution of plutonium tetrafluoride (Stir time: 1 hour).

\begin{tabular}{|c|c|c|}
\hline \multirow{2}{*}{$\begin{array}{c}\text { Solid-to-Liquid } \\
\text { Ratio }(\mathrm{g} / \mathrm{l}) \\
\end{array}$} & \multicolumn{2}{|c|}{ Plutonium Dissolved (\%) } \\
\hline & Temperature: Room $\left(24^{\circ} \mathrm{C}\right)$ & \\
\hline - & $\begin{array}{c}\text { Solvent: } 3 \underline{\mathrm{M}} \mathrm{HNO}_{3}+ \\
0.05 \mathrm{M} \mathrm{Al}\left(\mathrm{NO}_{3}\right)_{3} \cdot 9 \mathrm{H}_{2} \mathrm{O} \\
\end{array}$ & $\begin{array}{c}\text { Reflux } \\
15.7 \underline{\mathrm{M}} \mathrm{HNO}_{3} \\
\end{array}$ \\
\hline 100 & 8.3 & 54.3 \\
\hline 150 & 8.1 & 38.1 \\
\hline 200 & 11.3 & 43.1 \\
\hline 250 & 9.4 & 33.9 . \\
\hline 300 & 5.3 & 29.6 \\
\hline
\end{tabular}

plutonium dissolved in $3 \underline{\mathrm{M}} \mathrm{HNO}_{3}+0.05 \mathrm{Al}\left(\mathrm{NO}_{3}\right)_{3} \cdot 9 \mathrm{H}_{2} \mathrm{O}$ at room temperature was obtained at a solid-to-liquid ratio of $200 \mathrm{~g} / 1$, whereas the maximum at reflux temperature and $15.7 \mathrm{M} \mathrm{HNO}_{3}$ was at $100 \mathrm{~g} / \mathrm{l}$ and decreases as the solid-toliquid ratio was increased. The percent plutonium dissolved at reflux temperature was much higher at all solid-to-liquid ratios than the maximum dissolved at room temperature.

Rate of Dissolution: Figure 2 shows the effect of time on $\mathrm{PuF}_{4}$ dissolution at room and reflux temperatures. Plutonium tetrafluoride ( 12.5 grams per $50 \mathrm{ml}$ of solvent) was stirred for $0.25,0.50,1,2,4$, and 8 hours and the plutonium concentration measured. The rate of dissolution (slope of the curves) decreases after one hour at room temperature and after 2 hours at reflux temperature.

Nitric Acid Concentration: The effect of nitric acid concentration on the dissolution of plutonium tetrafluoride is shown in Figure 3. The dissolution was performed at room and reflux temperatures as described in the experimental procedure. The nitric acid concentration for optimum dissolution at room temperature was between 3 and 6 molar. Optimum dissolution at refluxing conditions requires 12 to 14 molar nitric acid.

\section{Addition of Fluoride Complexing Agent: The effect} of adding aluminum as a fluoride complexing agent on the dissolution of plutonium tetrafluoride is shown in Figure 4 for room temperature, and Figure 5 for reflux temperaturc. For room temperature, the highest dissolution was obtained in a solvent $3 \underline{\mathrm{M}}$ in $\mathrm{HNO}_{3}$ and $0.1 \mathrm{M}$ in $\mathrm{Al}\left(\mathrm{NO}_{3}\right)_{3} \cdot 9 \mathrm{H}_{2} \mathrm{O}$. For reflux temperature, the maximum dissolution was in the $9 \mathrm{M} \mathrm{HNO}_{3}-0.25 \mathrm{M} \mathrm{Al}\left(\mathrm{NO}_{3}\right)_{3}$. $9 \mathrm{H}_{2} \mathrm{O}$ system. The addition of $0.25 \mathrm{M} \mathrm{Al}\left(\mathrm{NO}_{3}\right)_{3} \cdot 9 \mathrm{H}_{2} \mathrm{O}$ increased the dissolution under reflux conditions approximately $14 \%$ over $9 \mathrm{M} \mathrm{HNO}_{3}$ having no aluminum. Increasing the aluminum concentration would probably increase dissolution even more, especially in $\left(9 \underline{\mathrm{M}} \mathrm{HNO}_{3}\right.$.

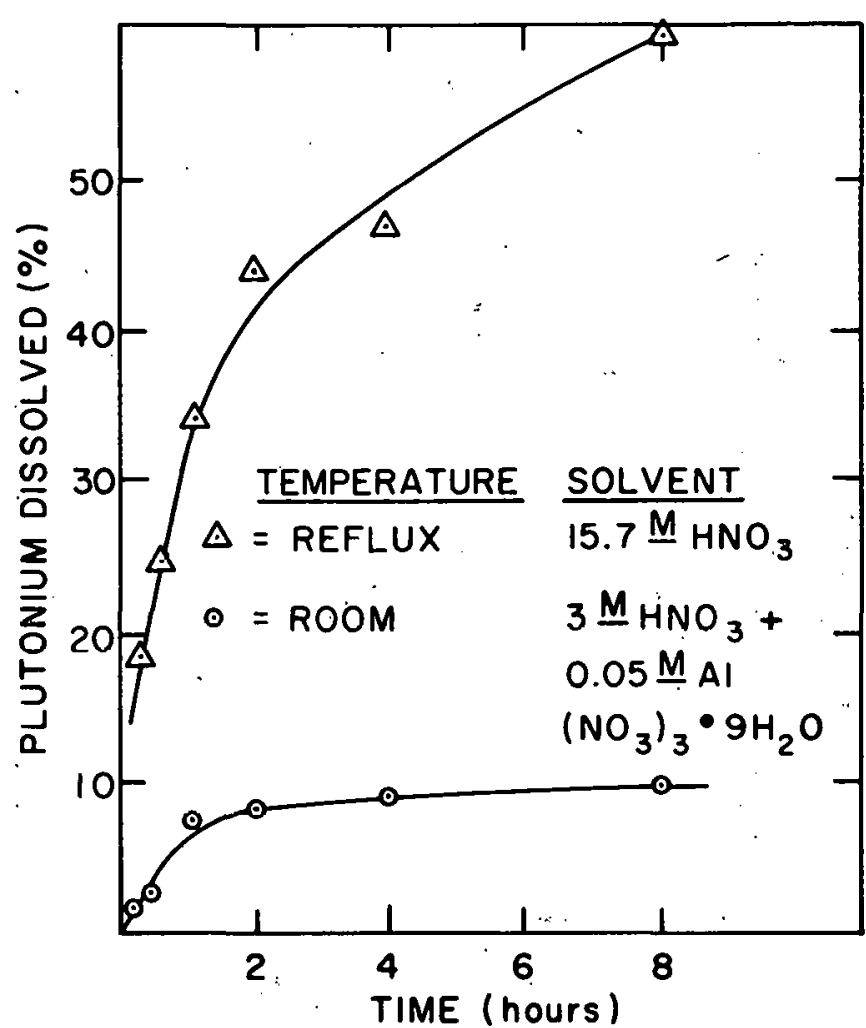

Figure 2. The effect of time on the dissolution of plutonium. tetrafluoride (Solid-to-liquid ratio $250 \mathrm{~g} / \mathrm{l}$ ).

Figure 3. The effect of nitric acid concentration on the dissolution of plutonium tetrafluoride (Solid-to-liquid ratio $250 \mathrm{~g} / 1$. Stir time: 1 hour).

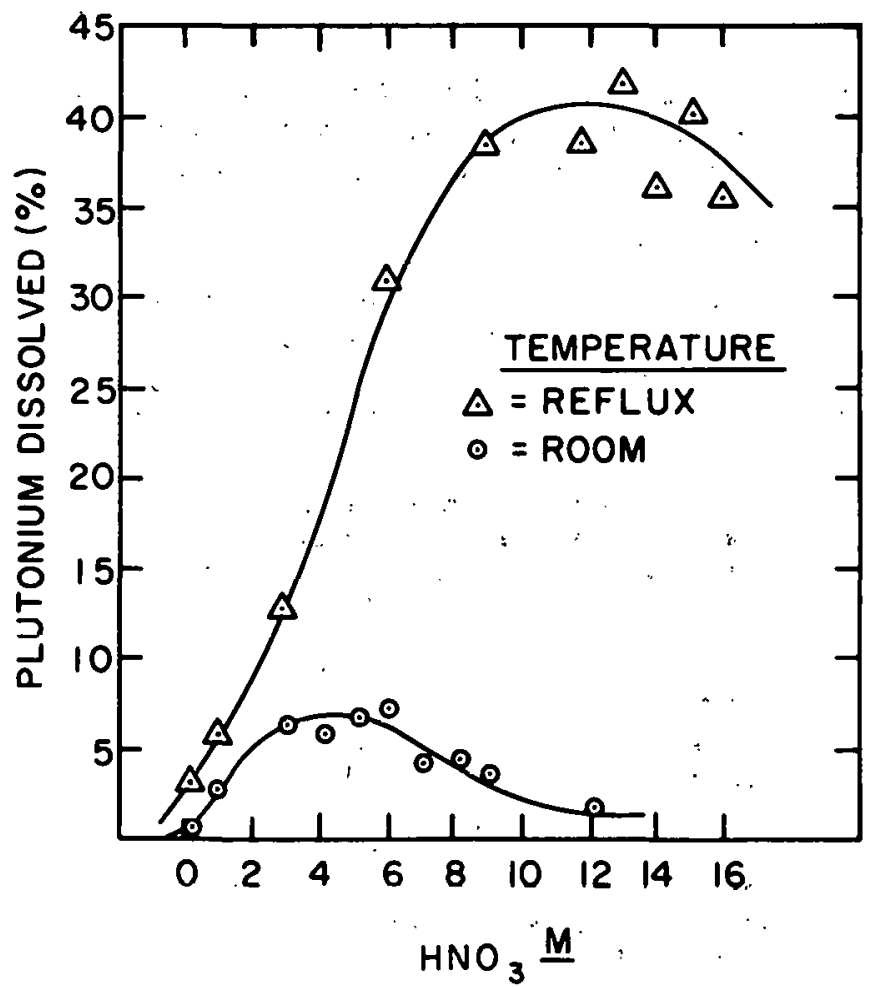




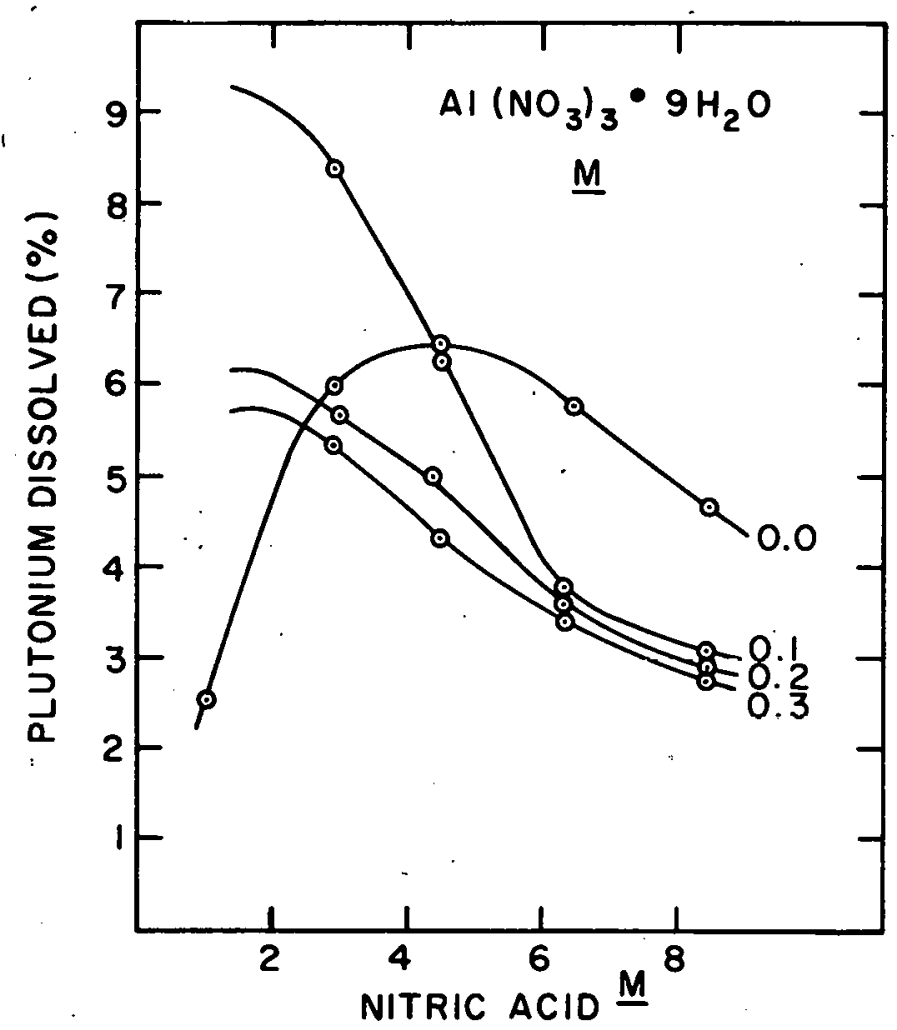

Figure 4. The effect of various aluminum nitrate and nitric acid concentrations on the dissolution of plutonium tetrafluoride at room temperature (Solid-to-liquid ratio 250 8/l. Stir time: 1 hour)

Several spot tests presented in Table IV indicate that boric acid addition also increases dissolution. This was also found to be the case using impure plutonium tetrafluoride. ${ }^{1}$

The addition of either aluminum or boron to increase the dissolution of plutonium tetrafluoride presumably

Table IV. The effect of different complexing agents on the dissolution of plutonium tetraffuoride at reflux temperature (Solid-to-liquid ratio $250 \mathrm{~g} / \mathrm{l}$. Stir time: 1 hour).

Solvent

Plutonium Dissolved (\%)

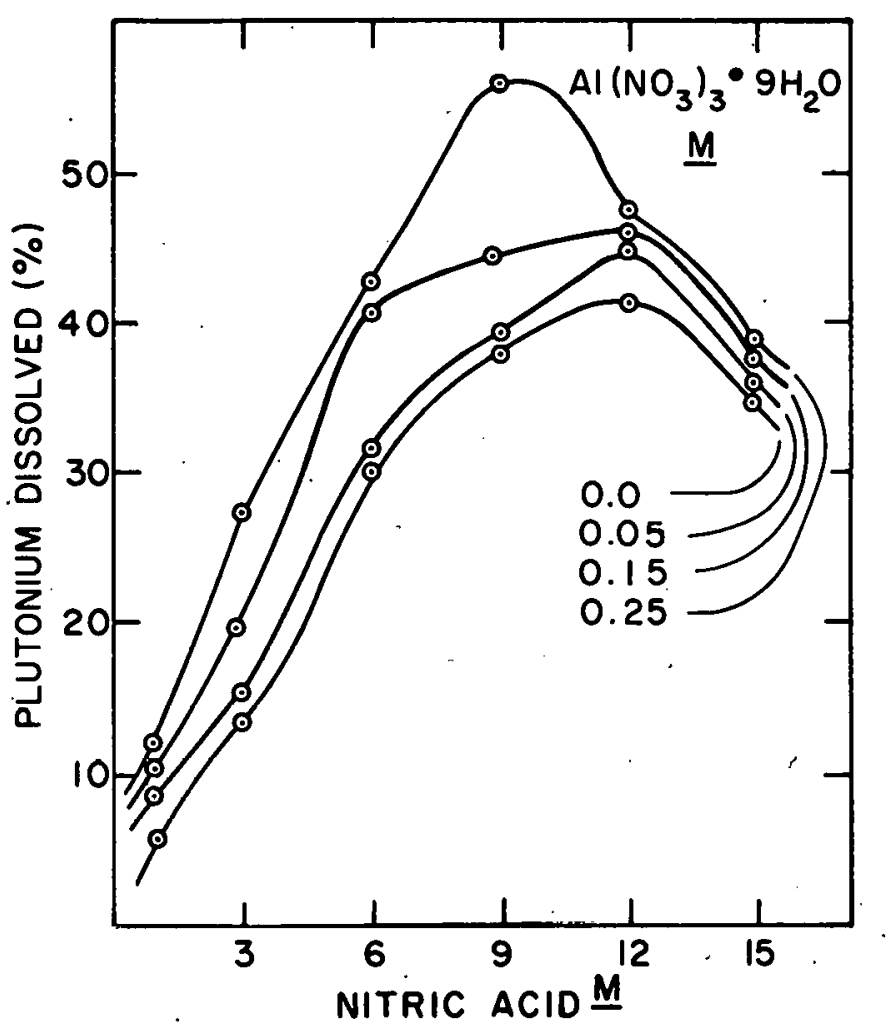

Figure 5. The effect of nitric acid and aluminum nitrate concentration on the dissolution of plutonium tetrafluoride at reflux temperature (solid-to-liquid ratio $250 \mathrm{~g} / \mathrm{l}$. Stir time: 1 hour).

would not affect the purity of the resultant metal if dissolution were followed by peroxide precipitation. These elements (Al and $B$ ) are not reported to precipitate with plutonium. ${ }^{6}$

Stored solutions from each test were observed one month after dissolution. Many were found to have precipitate (identified by $x$-ray diffraction as $\mathrm{PuF}_{4} \cdot 2.5 \mathrm{H}_{2} \mathrm{O}$ ) in the bottom of the container. The precipitated solutions were found in tests where nitric acid concentrations of 6 molar or less were used. No presipitate was found in solutions containing 9 molar, or greater, concentrations of nitric acid.

\section{REFERENCES}

1. J. D. Navratil, "Dissolution of Impure Plutonium Tetrafluoride in Nitric Acid," RFP.1118, Rocky Flats Division, The Dow Chemical Company, January 22, 1968 
RFP-1151

2. F. Meyer and H. Zvolner, "Chemical Research - Special Chemistry of Plutonium Report," CK-1763, July 1, 1944.

3. C. J. Mandleberg and K. E. Francis, "The Solubility of $\mathrm{PuF}_{4}$ in Nitric Acid Solutions and the Solubility Product of $\mathrm{PuF}_{4}$," A.E.R.E. C/R 865, February 20, 1952.

4. C. J. Mandleberg, K. E. Francis, and R. Smith, "The Solubility of Plutonium Trifluoride, Plutonium Tetra- fluoride, and Plutonium (IV) Oxalate in Nitric Acid Mixtures," J. Chem. Soc., 2464-68. (1961)

5. D. M. Creighton, "Solubility of Plutonium (IV) Fluoride in Nitric-Hydrofluoric Acids," RL-SEP-558, June 11, 1965.

6. J. A. Leary, A. N. Morgan, and W. J. Maraman, "Plutonium Peroxide Precipitation," Ind. and Eng. Chem. 51, 27-31. (1959) 